HEROES AND MARTYRS OF QUALITY AND SAFETY

\title{
Ignaz Semmelweis and the birth of infection control
}

\author{
M Best, D Neuhauser
}

Qual Saf Health Care 2004;13:233-234. doi: 10.1136/qshc.2004.010918

W orldwide, sepsis is the cause of death in about 1400 people each day. ${ }^{1}$ Many of these people develop sepsis from infections acquired as patients while in a hospital. Infections acquired in the hospital are called nosocomial infections. They are the most common complications of hospitalized patients, with $5-10 \%$ of patients in acute care hospitals acquiring at least one infection. Nosocomial infections occur in 2 million patients per year in the United States, causing 90000 deaths and resulting in \$4.5-5.7 billion in additional patient care costs. ${ }^{2}$

\section{INFECTION CONTROL}

Influenza virus, Legionnaires' disease, bacterial meningitis, measles, West Nile virus, tularemia, hepatitis A, rotavirus, Norwalk virus, multidrug resistant Pseudomonas, superresistant Klebsiella, methicillin resistant Staphylococcus aureus (MRSA), and vancomycin resistant Enterococcus are just a few of the infectious organisms and diseases that may be contracted while in hospital. Infection control is essential to limit the spread of these diseases. Cross-infection of patients by the contaminated hands of healthcare workers is a major method of spreading infectious agents. Hand hygiene is noted to be the single most important factor for infection control. Even today, hand washing is performed only one third to one half as often as it should be. ${ }^{3}$

\section{IGNAZ SEMMELWEIS (1818-1865)}

Known as the "father of infection control", Dr Ignaz (or Ignac) Semmelweis (fig l) was a Hungarian born physician who received his MD degree in Vienna in 1844. In 1847 he was given a 2 year appointment as an assistant in obstetrics with responsibility for the First Division of the maternity service of the vast Allgemeine Krankenhaus teaching hospital in Vienna. ${ }^{4}$ There he observed that women delivered by physicians and medical students had a much higher rate (13$18 \%$ ) of post-delivery mortality (called puerperal fever or childbed fever) than women delivered by midwife trainees or midwives $(2 \%)$.

This case-control analysis led Semmelweis to consider several hypotheses. He concluded that the higher rates of infections in women delivered by physicians and medical students were associated with the handling of corpses during autopsies before attending the pregnant women. This was not done by the midwives. He associated the exposure to cadaveric material with an increased risk of childbed fever, and conducted a study in which the intervention was hand washing.

\section{HAND WASHING}

Dr Semmelweis initiated a mandatory hand washing policy for medical students and physicians. In a controlled trial using a chloride of lime solution, ${ }^{6}$ the mortality rate fell to about $2 \%$-down to the same level as the midwives. Later he started washing the medical instruments and the rate decreased to about 1\%. His superior, Professor Klein, a member of the academic "old guard", did not accept his conclusions. Klein thought the lower mortality was due to

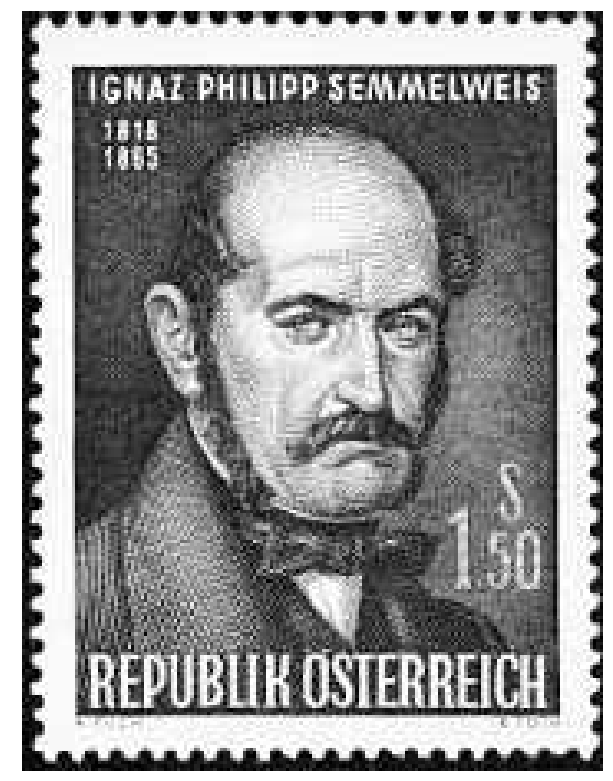

Figure 1 Postage stamp of Ignaz Philipp Semmelweis, 1818-1865. Issued in Austria in 1965 on the 100th anniversary of his death.

the hospital's new ventilation system, an idea that fitted the then popular miasmatic theory of disease. Semmelweis convinced a number of young faculty members who supported him. They were to become leaders of the next academic generation who would make the Allgemeine Krankenhaus the world's greatest teaching hospital for the next half century.

However, the senior staff won and Semmelweis did not get his assistant professorship renewed in 1849. He was offered a clinical faculty appointment (privatdozent) without permission to teach from cadavers. Feeling betrayed, he fled Vienna, abandoned his supporters, and went home to Budapest. In 1851 he was appointed head of obstetrics at St Rochus Hospital where he publicly harangued doctors and nurses about hand washing and reduced maternal mortality. In 1855 he gave up this position to become a professor at Pest University. In 1861 he published a book, "The Etiology, Concept, and Prophylaxis of Childbed Fever", but it was badly written and poorly received by the medical establishment. About 5 years later he died in a public insane asylum at the age of 47 .

Although Dr Semmelweis was the first healthcare professional to demonstrate experimentally that hand washing could prevent infections, ${ }^{7}$ it was not until approximately two decades after his death that his work was revisited and he was given credit. Only after Pasteur, Koch, and Lister had produced more evidence of the germ theory and antiseptic techniques was the value of hand washing appreciated.

\section{AN AGENT OF CHANGE}

Semmelweis made salient observations and identified a significant need for improvement in the process of patient 
care. There can be no doubt about that. However, he lacked change agent skills. First of all, and even though it proved to be one of the great medical publications of the 19th century, he did not publish his findings until 14 years after his observations. ${ }^{8}$ Without this evidence, his arrogance and dogmatism were not sufficiently convincing to overshadow the other competing theories of puerperal fever at that time. The germ theory of disease had not yet been developed. A popular theory of the day was that miasmas-a bad component in the air-was the cause. Furthermore, the calls for proof by his colleagues were interpreted as a personal insult. He responded by being rude to them and this made the situation worse. He wrote to one obstetrician in Vienna: "You, Herr Professor, have been a partner in this massacre." To another he wrote: "Should you, Herr Hofrath, without having disproved my doctrine, continue to train your pupils [against it], I declare before God and the world that you are a murderer and the 'History of Childbed Fever' would not be unjust to you if it memorialized you as a medical Nero." Some colleagues evaded or even sabotaged his hand washing regimen. ${ }^{9}$ He was not able to persuade others to see his vision for improvement. His frustration, rage, and ego all became obstacles for him to implement his changes for healthcare improvement.

Physicians resisted these changes for several reasons. Washing of hands before treating each patient would be too much work. In the long run, solving this problem would require rebuilding hospitals so that sinks and running water were within reach. The profession of being a physician was divinely blessed, so it would be unreasonable to think they could cause disease. Semmelweis was saying that doctors were the cause of death. Egos were often inversely proportional to the evidence, and the scientific evidence was very scant at this time.

\section{HERO OR MARTYR?}

A hero of quality and safety has to be able both to discover opportunities for improvement and to implement the system changes necessary for the improvement. Semmelweis succeeded in the first and failed in the second. He was a martyr in his life time and later a hero-the "savior of mothers". On the 100th anniversary of his death Austria issued a postage stamp in his honor (fig l) and the Budapest medical school at which he taught is now the Semmelweis University of Medicine.

\section{BUT AS A CHANGE AGENT?}

Insult your enemies, accuse your superiors of causing the deaths of mothers, actively join academic political factions, abandon your friends, refuse to publish, but when you do so write incomprehensibly, use public humiliation and haranguing to change behaviour, and be arrogant and angry yourself. This will not work every time.

\section{Authors' affiliations}

M Best, D Neuhauser, Department of Epidemiology and Biostatistics, Case School of Medicine, Case Western Reserve University, Cleveland, Ohio, USA

Correspondence to: Professor D Neuhauser, Department of Epidemiology and Biostatistics, Case School of Medicine, Case Western Reserve University, Cleveland, OH 44106-4945, USA; dvn@case.edu

\section{REFERENCES}

1 Bone RC, et al. Definitions for sepsis and organ failure and guidelines for the use of innovative therapies in sepsis. The ACCP/SCCM Consensus Conference Committee. Chest 1992;101:1644-55.

2 Burke JP. Infection control-a problem for patient safety. N Engl J Med 2003;348:651-6.

3 Gawande A. On washing hands. N Engl J Med 2004;350:1283-6.

4 Loudon I. Commentary on Semelweiss I (1818-1865). The James Lind Library.www.jameslindlibrary.org (accessed 23 December 2003).

5 Caplan CE. The childbed fever mystery and the meaning of medical journalism. www.med.mcgill.ca/mjm/issues/v01 n01/fever.html (accessed 23 December 2003).

6 Miles S. Research retrospective-notes from earlier trials. www.kelcom.igs.net/ nhodgins/retrospective_semmelweis.html (accessed 23 December 2003).

7 John M. Hand hygiene: washing and disinfection. J Can Dent Assoc 2000;66:546-7.

8 Semmelweis IP. The cause, concept and prophylaxis of childbed fever 1861.

9 Nuland SB. The doctors' plague: germs, childhood fever, and the strange story of Ignac Semmelweis. New York: WW Norton, 2003. 